\title{
Asymmetric Synthesis of
}

\section{3-Azide-4-fluoro-L-phenylalanine}

\author{
Masaatsu Adachi, * Mado Nakajima, Minoru Isobe* \\ Laboratory of Organic Chemistry, Graduate School of Bioagricultural Sciences, \\ Nagoya University, \\ Chikusa, Nagoya 464-8601, Japan
}

Supporting Information

\section{Index}

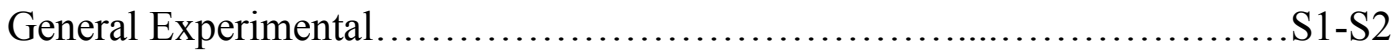

Experimental Procedures and Characterization Data.....................S3-S8

\section{General Experimental}

Optical rotations were measured on a JASCO DIP-370 digital polarimeter. Infrared spectra (IR) were recorded on a JASCO FT/IR-8300 spectrophotometer and are reported in wave number $\left(\mathrm{cm}^{-1}\right)$. Proton nuclear magnetic resonance $\left({ }^{1} \mathrm{H}\right.$ NMR) spectra were recorded on a Bruker ARX-400 (400 MHz) spectrometer. NMR samples were dissolved in $\mathrm{CDCl}_{3}$ and $\mathrm{DMSO}$, and chemical shifts are reported in ppm relative to the residual undeuterated solvent $\left(\mathrm{CDCl}_{3}\right.$ as $\delta=7.26 \mathrm{ppm}$, DMSO as $\left.\delta=2.50 \mathrm{ppm}\right)$. ${ }^{1} \mathrm{H}$ NMR data are reported as follows; chemical shift, integration, multiplicity ( $\mathrm{s}=$ singlet, $\mathrm{d}=$ doublet, $\mathrm{t}=$ triplet, $\mathrm{q}=$ quartet, $\mathrm{br}=$ broadened, $\mathrm{m}=$ multiplet), coupling constant, and assignment. Carbon nuclear magnetic resonance $\left({ }^{13} \mathrm{C}\right.$ NMR $)$ spectra were recorded on a Bruker ARX-400 (100 MHz) or a Varian Gemini-2000 (75 MHz) spectrometer. The samples were dissolved in $\mathrm{CDCl}_{3}$ and DMSO, and chemical shifts are reported in ppm relative to the solvent $\left(\mathrm{CDCl}_{3}\right.$ as $\delta=77.0 \mathrm{ppm}$, DMSO as $\left.\delta=39.5 \mathrm{ppm}\right)$. Fluorine nuclear magnetic resonance $\left({ }^{19} \mathrm{~F}\right.$ NMR) spectra were recorded on a Brucker ARX-400 $(376 \mathrm{MHz})$ spectrometer. Elemental analyses were performed at the Analytical 
Laboratory of the Graduate School of Bioagricultural Sciences, Nagoya University. High resolution mass spectra (HRMS) were recorded on a JEOL JMS-700 are reported in $m / z$. Reactions were monitored by thin-layer chromatography (TLC) on $0.25 \mathrm{~mm}$ silica gel coated glass plate $60 \mathrm{~F}_{254}$ (Merck, \#1.05715). Silica gel 60 (particle size 63-200 $\mu \mathrm{m}$, 70-230 mesh ASTM, Merck Ltd.) was used for open-column chromatography. Silica gel 60 (spherical, particle size 40-50 $\mu \mathrm{m}$, Kanto Chemical Co., Inc.) and silica gel $60 \mathrm{~N}$ (spherical, neutral, particle size 40-50 $\mu \mathrm{m}$, Kanto Chemical Co., Inc.) were used for flash column chromatography. Unless otherwise noted, non-aqueous reactions were carried out in oven-dried $\left(120^{\circ} \mathrm{C}\right)$ or flame-dried glassware under nitrogen or argon. Dry THF and $\mathrm{CH}_{2} \mathrm{Cl}_{2}$ were purchased from Kanto Chemical Co., Inc. All other commercially available reagents were used as received. 


\section{Experimental Procedures and Characterization Data}<smiles>O=Cc1ccc(F)c([N+](=O)[O-])c1</smiles>

5

Aldehyde 5: In a $300 \mathrm{~mL}$ flask equipped with a dropping funnel, 95\% $\mathrm{H}_{2} \mathrm{SO}_{4}(80 \mathrm{~mL})$ and $69 \% \mathrm{HNO}_{3}(11.0 \mathrm{~mL}, 169 \mathrm{mmol})$ were placed, and it was cooled to $0{ }^{\circ} \mathrm{C}$. p-Fluorobenzaldehyde $4(17.2 \mathrm{~mL}, 161 \mathrm{mmol})$ was added dropwise over $10 \mathrm{~min}$. The reaction mixture was allowed to warm to room temperature. After being stirred for $1 \mathrm{~h}$, the reaction mixture was poured into ice $(200 \mathrm{~g})$. The resultant solution was extracted with $\mathrm{CH}_{2} \mathrm{Cl}_{2}(200 \mathrm{~mL} \times 2)$. The organic layer was washed with $\mathrm{H}_{2} \mathrm{O}$ and brine, and the dried over $\mathrm{Na}_{2} \mathrm{SO}_{4}$. The solution was concentrated to dryness in vacuo. The residue was purified by recrystallization (from $\mathrm{Et}_{2} \mathrm{O}$-hexane) to give $5(18.3 \mathrm{~g}, 67 \%)$ as a yellow powder.

IR (KBr) $v_{\max } 3067,2859,1705,1615,1542,1351 \mathrm{~cm}^{-1} ;{ }^{1} \mathrm{H}$ NMR (400 MHz, $\left.\mathrm{CDCl}_{3}\right)$ $\delta 7.51(1 \mathrm{H}, \mathrm{dd}, J=10.0,8.5 \mathrm{~Hz}), 8.21$ (1H, ddd, $J=8.5,4,2 \mathrm{~Hz}), 8.59$ (1H, dd, $J=7,2$ $\mathrm{Hz}), 10.05(1 \mathrm{H}, \mathrm{s}) ;{ }^{13} \mathrm{C} \mathrm{NMR}\left(100 \mathrm{MHz}, \mathrm{CDCl}_{3}\right) \delta 119.7\left(\mathrm{~d}, J_{\mathrm{C}-\mathrm{F}}=22 \mathrm{~Hz}\right), 127.8 \mathrm{x} 2$, 133.0, $135.6\left(\mathrm{~d}, J_{\mathrm{C}-\mathrm{F}}=10 \mathrm{~Hz}\right), 158.7\left(\mathrm{~d}, J_{\mathrm{C}-\mathrm{F}}=274 \mathrm{~Hz}\right), 188.2 ;{ }^{19} \mathrm{~F}$ NMR $(376 \mathrm{MHz}$, $\left.\mathrm{CDCl}_{3}\right) \delta-107.9$; HRMS (EI) for $\mathrm{C}_{7} \mathrm{H}_{4} \mathrm{FNO}_{3}\left[\mathrm{M}^{+}\right]$, calcd 169.0175, found: 169.0157.<smiles>Nc1cc(CO)ccc1F</smiles>

6

Alcohol 6: In a flask equipped with a dropping funnel, aldehyde 5 (5.0 g, $31.0 \mathrm{mmol})$ was dissolved in $\mathrm{MeOH}(30 \mathrm{~mL})$, and it was cooled to $0{ }^{\circ} \mathrm{C}$. To this solution was added a solution of $\mathrm{NaBH}_{4}(1.76 \mathrm{~g}, 47.0 \mathrm{mmol})$ in $\mathrm{H}_{2} \mathrm{O}(7.5 \mathrm{~mL})$ dropwise over $20 \mathrm{~min}$. After being stirred at room temperature for $1 \mathrm{~h}$, the reaction mixture was concentrated in vacuo. The aqueous layer was neutralized with $1 N$ aqueous $\mathrm{HCl}$ and extracted with $\mathrm{Et}_{2} \mathrm{O}(150 \mathrm{~mL} \mathrm{x} 2)$. The organic layer was washed with brine $(100 \mathrm{~mL} \times 2)$, and then dried over $\mathrm{Na}_{2} \mathrm{SO}_{4}$. The solution was concentrated to dryness in vacuo. The residue was 
used for the next reaction without further purification.

The residue was dissolved in $\mathrm{EtOH}(50 \mathrm{~mL})$, and $10 \% \mathrm{Pd} / \mathrm{C}(100 \mathrm{mg})$ was added. The reaction vessel was charged with $\mathrm{H}_{2}$ gas. After being stirred vigorously at room temperature for $16 \mathrm{~h}$, the reaction mixture was filtered through a pad of Celite. The filtrate was concentrated to dryness in vacuo. The residue was used for the next reaction without further purification.

The residue was dissolved in a mixture of $\mathrm{AcOH}(50 \mathrm{~mL})$, TFA $(5 \mathrm{~mL})$ and $\mathrm{H}_{2} \mathrm{O}(5 \mathrm{~mL})$, and it was cooled to $3{ }^{\circ} \mathrm{C}$. To this solution was added $\mathrm{NaNO}_{2}(3.2 \mathrm{~g}, 46.0 \mathrm{mmol})$ and the solution was stirred for $10 \mathrm{~min}$. To the solution was added $\mathrm{NaN}_{3}(3.0 \mathrm{~g}, 46.0 \mathrm{mmol})$ at the same temperature. After being stirred for additional $10 \mathrm{~min}$, the reaction mixture was poured into an ice-cooled saturated aqueous $\mathrm{NaHCO}_{3}(200 \mathrm{~mL})$. The resultant solution was extracted with AcOEt $(300 \mathrm{~mL} \times 1)$. The organic layer was washed with saturated aqueous $\mathrm{NaHCO}_{3}(50 \mathrm{~mL} \times 3)$ and brine, and then dried over $\mathrm{Na}_{2} \mathrm{SO}_{4}$. The solution was concentrated to dryness in vacuo. The residue was purified by column chromatography (silica gel, AcOEt/hexane 1:5) to give 6 (3.53 g, 68\% in 3 steps) as a dark red oil.

IR (KBr) $v_{\max } 3323,2127,1607,1514,1424,1317,1228 \mathrm{~cm}^{-1} ;{ }^{1} \mathrm{H}$ NMR (400 MHz, $\left.\mathrm{CDCl}_{3}\right) \delta 1.79(1 \mathrm{H}, \mathrm{br} \mathrm{s}), 4.65(2 \mathrm{H}, \mathrm{s}), 7.04-7.12(3 \mathrm{H}, \mathrm{m}) ;{ }^{13} \mathrm{C} \mathrm{NMR}\left(100 \mathrm{MHz}, \mathrm{CDCl}_{3}\right)$ $\delta 64.1,116.6\left(\mathrm{~d}, J_{\mathrm{C}-\mathrm{F}}=19 \mathrm{~Hz}\right), 119.4,124.0\left(\mathrm{~d}, J_{\mathrm{C}-\mathrm{F}}=7 \mathrm{~Hz}\right), 127.9\left(\mathrm{~d}, J_{\mathrm{C}-\mathrm{F}}=11 \mathrm{~Hz}\right)$, $137.9\left(\mathrm{~d}, J_{\mathrm{C}-\mathrm{F}}=3 \mathrm{~Hz}\right), 154.1\left(\mathrm{~d}, J_{\mathrm{C}-\mathrm{F}}=249 \mathrm{~Hz}\right) ;{ }^{19} \mathrm{~F}$ NMR $\left(376 \mathrm{MHz}, \mathrm{CDCl}_{3}\right) \delta-128.2$; HRMS (EI) for $\mathrm{C}_{7} \mathrm{H}_{6} \mathrm{FN}_{3} \mathrm{O}\left[\mathrm{M}^{+}\right]$, calcd 167.0495, found: 167.0490.<smiles>Nc1cc(CBr)ccc1F</smiles>

$7 a$

Bromide 7a: Alcohol 6 (5.96 g, $35.7 \mathrm{mmol})$ was dissolved in $\mathrm{CH}_{2} \mathrm{Cl}_{2}(120 \mathrm{~mL})$, and it was cooled to $0{ }^{\circ} \mathrm{C}$. To this solution was added $\mathrm{CBr}_{4}(21.7 \mathrm{~g}, 65.4 \mathrm{mmol})$ and $\mathrm{PPh}_{3}(13.6$ $\mathrm{g}, 52.3 \mathrm{mmol}$ ) at the same temperature. After being stirred at room temperature for 20 min, the reaction mixture was concentrated in vacuo to remove three-quarters of the solvent. The resulting mixture was passed through a column packed with flash silica gel (eluted with $\mathrm{CH}_{2} \mathrm{Cl}_{2}$ ), and then concentrated to dryness in vacuo. The residue was 
purified by flash column chromatography (silica gel, $\mathrm{Et}_{2} \mathrm{O} /$ hexane 1:65) to give 7a (4.95 $\mathrm{g}, 60 \%)$ as a yellow oil.

IR (KBr) $v_{\max } 2125,1607,1514,1420,1319 \mathrm{~cm}^{-1} ;{ }^{1} \mathrm{H}$ NMR $\left(400 \mathrm{MHz}, \mathrm{CDCl}_{3}\right) \delta 4.41$ $(2 \mathrm{H}, \mathrm{s}), 7.02-7.14(3 \mathrm{H}, \mathrm{m}) ;{ }^{13} \mathrm{C} \mathrm{NMR}\left(100 \mathrm{MHz}, \mathrm{CDCl}_{3}\right) \delta 31.7,117.0\left(\mathrm{~d}, J_{\mathrm{C}-\mathrm{F}}=19 \mathrm{~Hz}\right)$, 121.7, $126.4\left(\mathrm{~d}, J_{\mathrm{C}-\mathrm{F}}=8 \mathrm{~Hz}\right), 128.3\left(\mathrm{~d}, J_{\mathrm{C}-\mathrm{F}}=12 \mathrm{~Hz}\right), 134.9\left(\mathrm{~d}, J_{\mathrm{C}-\mathrm{F}}=4 \mathrm{~Hz}\right), 154.7(\mathrm{~d}$, $\left.J_{\mathrm{C}-\mathrm{F}}=251 \mathrm{~Hz}\right) ;{ }^{19} \mathrm{~F}$ NMR $\left(376 \mathrm{MHz}, \mathrm{CDCl}_{3}\right) \delta-126.2$; HRMS (EI) for $\mathrm{C}_{7} \mathrm{H}_{5} \mathrm{BrFN}_{3}$ $\left[\mathrm{M}^{+}\right]$, calcd 228.9651, found: 228.9630 .

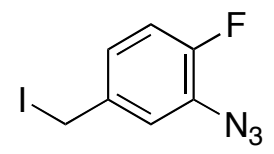

$7 f$

Iodide 7f: Bromide 7a (4.9 g, $21.0 \mathrm{mmol})$ was dissolved in acetone (160 mL), and it was cooled to $0{ }^{\circ} \mathrm{C}$ under nitrogen. To this solution was added $\mathrm{NaHCO}_{3}(9.0 \mathrm{~g}, 107$ $\mathrm{mmol})$ and $\mathrm{NaI}(19.2 \mathrm{~g}, 128 \mathrm{mmol})$ at the same temperature. After being stirred at room temperature for $3 \mathrm{~h}$, the reaction mixture was poured into an ice-cooled water. The resultant solution was extracted with AcOEt $(400 \mathrm{~mL} \times 1)$. The organic layer was washed with brine $(400 \mathrm{~mL} \times 2)$, and then dried over $\mathrm{Na}_{2} \mathrm{SO}_{4}$. The solution was concentrated to dryness in vacuo. The residue was purified by column chromatography (neutral silica gel, $\mathrm{Et}_{2} \mathrm{O} /$ hexane $\left.1: 19\right)$ to give $7 \mathbf{f}(5.64 \mathrm{~g}, 96 \%)$ as a yellow oil.

IR (KBr) $v_{\max } 2121,1605,1513,1420,1319 \mathrm{~cm}^{-1} ;{ }^{1} \mathrm{H}$ NMR $\left(400 \mathrm{MHz}, \mathrm{CDCl}_{3}\right) \delta 4.38$ $(2 \mathrm{H}, \mathrm{s}), 7.01(1 \mathrm{H}, \mathrm{dd}, J=10.5,8.5 \mathrm{~Hz}), 7.05-7.12(2 \mathrm{H}, \mathrm{m}) ;{ }^{13} \mathrm{C} \mathrm{NMR}(100 \mathrm{MHz}$, $\left.\mathrm{CDCl}_{3}\right) \delta 3.2,117.0\left(\mathrm{~d}, J_{\mathrm{C}-\mathrm{F}}=19 \mathrm{~Hz}\right), 121.3,126.1\left(\mathrm{~d}, J_{\mathrm{C}-\mathrm{F}}=7 \mathrm{~Hz}\right), 128.2\left(\mathrm{~d}, J_{\mathrm{C}-\mathrm{F}}=12\right.$ $\mathrm{Hz}), 136.5\left(\mathrm{~d}, J_{\mathrm{C}-\mathrm{F}}=4 \mathrm{~Hz}\right), 154.2\left(\mathrm{~d}, J_{\mathrm{C}-\mathrm{F}}=251 \mathrm{~Hz}\right) ;{ }^{19} \mathrm{~F}$ NMR $\left(376 \mathrm{MHz}, \mathrm{CDCl}_{3}\right)$ $\delta$-126.8; HRMS (EI) for $\mathrm{C}_{7} \mathrm{H}_{5} \mathrm{FIN}_{3}\left[\mathrm{M}^{+}\right]$, calcd 276.9512, found: 276.9501 . 


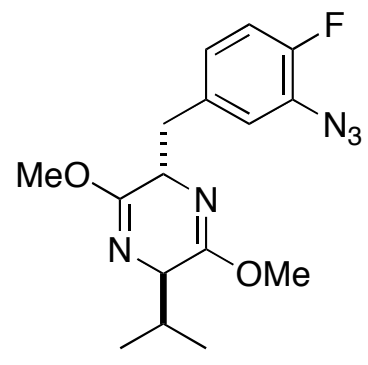

$8 a$

Compound 8a: Bislactim ether 2 (400 mg, $2.17 \mathrm{mmol})$ was dissolved in dry THF (5.8 $\mathrm{mL}$ ), and it was cooled to $-78{ }^{\circ} \mathrm{C}$ under nitrogen. To this solution was added $n$-BuLi (1.6 $\mathrm{M}$ solution in hexane; $1.35 \mathrm{~mL}, 2.17 \mathrm{mmol}$ ) dropwise over $5 \mathrm{~min}$. After the solution was stirred at the same temperature for $30 \mathrm{~min}, \mathrm{BF}_{3} \cdot \mathrm{OEt}_{2}(410 \mu \mathrm{L}, 3.20 \mathrm{mmol})$ was added. The resultant slurry solution was stirred for $30 \mathrm{~min}$, and a solution of 3-azide-4-fluoro benzyl iodide 7 f $(450 \mathrm{mg}, 1.73 \mathrm{mmol})$ in THF $(3.6 \mathrm{~mL})$ was added dropwise at $-78{ }^{\circ} \mathrm{C}$ over $30 \mathrm{~min}$. After being stirred for additional $1 \mathrm{~h}$, the reaction mixture was quenched with a mixture of saturated aqueous $\mathrm{NH}_{4} \mathrm{Cl}(7.2 \mathrm{~mL})$ and aqueous ammonia $(28 \%, 0.8 \mathrm{~mL})$. The resultant solution was extracted with $\mathrm{Et}_{2} \mathrm{O}(30$ $\mathrm{mL} \times 1)$. The organic layer was washed with water and brine, and then dried over anhydrous $\mathrm{Na}_{2} \mathrm{SO}_{4}$. The solution was concentrated to dryness in vacuo. The residue was purified by column chromatography (neutral silica gel, $\mathrm{Et}_{2} \mathrm{O} /$ hexane 1:4) to give 8a (472 $\mathrm{mg}, 82 \%$ ) as a yellow oil.

$[\alpha]_{\mathrm{D}}{ }^{29}+36\left(c 0.87, \mathrm{CHCl}_{3}\right)$; IR (KBr) $v_{\max } 2945,2124,1697,1514,1239 \mathrm{~cm}^{-1} ;{ }^{1} \mathrm{H} \mathrm{NMR}$ $\left(400 \mathrm{MHz}, \mathrm{CDCl}_{3}\right) \delta 0.64(3 \mathrm{H}, \mathrm{d}, J=7 \mathrm{~Hz}), 0.97(3 \mathrm{H}, \mathrm{d}, J=7 \mathrm{~Hz}), 2.17(1 \mathrm{H}, \mathrm{m}), 3.04$ $(2 \mathrm{H}, \mathrm{brd}, J=5 \mathrm{~Hz}), 3.48(1 \mathrm{H}, \mathrm{t}, J=4.0 \mathrm{~Hz}), 3.67(3 \mathrm{H}, \mathrm{s}), 3.71(3 \mathrm{H}, \mathrm{s}), 4.27(1 \mathrm{H}, \mathrm{br} \mathrm{q}, J$ $=5 \mathrm{~Hz}), 6.82(1 \mathrm{H}, \mathrm{m}), 6.87(1 \mathrm{H}, \mathrm{dd}, J=8.0,2.0 \mathrm{~Hz}), 6.98(1 \mathrm{H}, \mathrm{dd}, J=10.5,8.5 \mathrm{~Hz})$; ${ }^{13} \mathrm{C}$ NMR $\left(100 \mathrm{MHz}, \mathrm{CDCl}_{3}\right) \delta 16.5,19.0,31.5,39.1,52.2,52.4,56.3,60.5,116.0(\mathrm{~d}$, $\left.J_{\mathrm{C}-\mathrm{F}}=19 \mathrm{~Hz}\right), 122.2,126.9\left(\mathrm{~d}, J_{\mathrm{C}-\mathrm{F}}=11 \mathrm{~Hz}\right), 127.2\left(\mathrm{~d}, J_{\mathrm{C}-\mathrm{F}}=6 \mathrm{~Hz}\right), 134.6,153.5,(\mathrm{~d}$, $\left.J_{\mathrm{C}-\mathrm{F}}=248 \mathrm{~Hz}\right), 162.0,164.1 ;{ }^{19} \mathrm{~F}$ NMR $\left(376 \mathrm{MHz}, \mathrm{CDCl}_{3}\right) \delta-130.1$; HRMS (EI) for $\mathrm{C}_{16} \mathrm{H}_{20} \mathrm{FN}_{5} \mathrm{O}_{2}\left[\mathrm{M}^{+}\right]$, calcd 333.1601, found: 333.1591 . 
<smiles>COC(=O)[C@H](N)Cc1ccc(F)c(N)c1</smiles>

9

Methyl ester 9: Compound 8a (300 mg, $0.90 \mathrm{mmol})$ was dissolved in THF (3.6 mL), and it was cooled to $0{ }^{\circ} \mathrm{C}$. To this solution was added $2 \mathrm{~N}$ aqueous $\mathrm{HCl}(3.0 \mathrm{~mL})$. The reaction mixture was allowed to warm to room temperature and stirred for $1 \mathrm{~h}$. The reaction mixture was cooled to $0{ }^{\circ} \mathrm{C}$ and adjusted to $\mathrm{pH} 9$ with $1 N$ aqueous ammonia $(6.0 \mathrm{~mL})$. The solution was concentrated to dryness in vacuo. The aqueous layer was extracted with $\mathrm{CH}_{2} \mathrm{Cl}_{2}(20 \mathrm{~mL} \times 3)$. The organic layer was washed with brine, and then dried over $\mathrm{Na}_{2} \mathrm{SO}_{4}$. The solution was concentrated to dryness in vacuo. The residue was purified by column chromatography (silica gel, $\mathrm{MeOH} / \mathrm{CH}_{2} \mathrm{Cl}_{2} 1: 19$ ) to give 9 (172 mg, $81 \%)$ as a yellow amorphous.

$[\alpha]_{\mathrm{D}}{ }^{27}+14.8\left(c 1.60, \mathrm{CHCl}_{3}\right)$; IR (KBr) $v_{\max } 2953,2124,1736,1605,1514 \mathrm{~cm}^{-1} ;{ }^{1} \mathrm{H}$ NMR (400 MHz, $\left.\mathrm{CDCl}_{3}\right) \delta 1.65(2 \mathrm{H}$, br s), $2.83(1 \mathrm{H}, \mathrm{dd}, J=14,7.5 \mathrm{~Hz}), 3.03(1 \mathrm{H}, \mathrm{dd}$, $J=14,5 \mathrm{~Hz}), 3.72(1 \mathrm{H}, \mathrm{m}), 3.74(3 \mathrm{H}, \mathrm{s}), 6.88-6.95(2 \mathrm{H}, \mathrm{m}), 7.02(1 \mathrm{H}, \mathrm{m}) ;{ }^{13} \mathrm{C} \mathrm{NMR}$ $\left(75 \mathrm{MHz}, \mathrm{CDCl}_{3}\right) \delta 40.2,52.2,55.7,116.7\left(\mathrm{~d}, J_{\mathrm{C}-\mathrm{F}}=19 \mathrm{~Hz}\right), 121.8,126.6\left(\mathrm{~d}, J_{\mathrm{C}-\mathrm{F}}=7\right.$ $\mathrm{Hz}), 127.9\left(\mathrm{~d}, J_{\mathrm{C}-\mathrm{F}}=11 \mathrm{~Hz}\right), 134.5\left(\mathrm{~d}, J_{\mathrm{C}-\mathrm{F}}=3 \mathrm{~Hz}\right), 154.1\left(\mathrm{~d}, J_{\mathrm{C}-\mathrm{F}}=249 \mathrm{~Hz}\right), 175.4 ;{ }^{19} \mathrm{~F}$ NMR (376 MHz, $\left.\mathrm{CDCl}_{3}\right) \delta-129.2$; HRMS (EI) for $\mathrm{C}_{10} \mathrm{H}_{11} \mathrm{FN}_{4} \mathrm{O}_{2}\left[\mathrm{M}^{+}\right]$, calcd 238.0866, found: 238.0868 .<smiles>O=C(O)N[C@@H](Cc1ccc(F)c([N+](=O)[O-])c1)C(=O)O</smiles>

1

Phenylalanine 1: Methyl ester $9(127 \mathrm{mg}, 0.53 \mathrm{mmol})$ was dissolved in dioxane (1.8 $\mathrm{mL})$. To this solution was added a solution of $\mathrm{LiOH}(45 \mathrm{mg})$ in $\mathrm{H}_{2} \mathrm{O}(3.6 \mathrm{~mL})$ at room temperature. After being stirred for $5 \mathrm{~min}$, the reaction mixture was neutralized to $\mathrm{pH} 7$ 
with $1 N$ aqueous $\mathrm{HCl}$.

To the solution was added $\mathrm{NaHCO}_{3}(225 \mathrm{mg}, 2.66 \mathrm{mmol})$ followed by a solution of $\mathrm{N}$-(9-fluorenylmethoxycarbonyloxy)succinimide $(215 \mathrm{mg}, 0.64 \mathrm{mmol})$ in dioxane $(4.8$ $\mathrm{mL}$ ) at room temperature. After being stirred at the same temperature for $40 \mathrm{~min}$, the reaction mixture was adjusted to $\mathrm{pH} 1$ with $1 \mathrm{~N}$ aqueous $\mathrm{HCl}$. The resultant solution was extracted with AcOEt (20 mL x2). The organic layer was washed with brine, and then dried over $\mathrm{Na}_{2} \mathrm{SO}_{4}$. The solution was concentrated to dryness in vacuo. The residue was purified by column chromatography (silica gel, $\mathrm{AcOH} / \mathrm{MeOH} / \mathrm{CH}_{2} \mathrm{Cl}_{2}$ 0.5:10:90) to give 1 (220 mg, 92\% in 2 steps) as a white solid.

$[\alpha]_{\mathrm{D}}{ }^{26}+37\left(\mathrm{c} 0.80, \mathrm{CHCl}_{3}\right)$; IR (KBr) $v_{\max } 3295,2363,2124,1697,1589,1514 \mathrm{~cm}^{-1} ;{ }^{1} \mathrm{H}$ NMR (400 MHz, DMSO- $\left.d_{6}\right) \delta 2.90(1 \mathrm{H}, \mathrm{dd}, J=14,11 \mathrm{~Hz}), 3.14(1 \mathrm{H}, \mathrm{dd}, J=14,4 \mathrm{~Hz})$, $3.38(1 \mathrm{H}$, br s), 4.16-4.29 (4H, m), $7.14(1 \mathrm{H}, \mathrm{m}), 7.20-7.37(4 \mathrm{H}, \mathrm{m}), 7.44(2 \mathrm{H}, \mathrm{t}, J=7.5$ $\mathrm{Hz}), 7.66(2 \mathrm{H}, \mathrm{d}, J=7.5 \mathrm{~Hz}), 7.75(1 \mathrm{H}, \mathrm{d}, J=8.6 \mathrm{~Hz}), 7.91(2 \mathrm{H}, \mathrm{d}, J=7.5 \mathrm{~Hz}) ;{ }^{13} \mathrm{C}$ NMR (100 MHz, DMSO-d $d_{6} \delta 35.4,46.5,55.1,65.6,116.3\left(\mathrm{~d}, J_{\mathrm{C}-\mathrm{F}}=18.4 \mathrm{~Hz}\right), 120.0$, $121.9,125.1,126.4\left(\mathrm{~d}, J_{\mathrm{C}-\mathrm{F}}=11 \mathrm{~Hz}\right), 126.9,127.6,135.5,140.6,143.6,143.7,152.5$ (d, $\left.J_{\mathrm{C}-\mathrm{F}}=243.9 \mathrm{~Hz}\right), 155.9,173.0 ;{ }^{19} \mathrm{~F}$ NMR (376 MHz, DMSO- $\left.d_{6}\right) \delta-125.7$; Anal. Calcd. for $\mathrm{C}_{24} \mathrm{H}_{19} \mathrm{FN}_{4} \mathrm{O}_{4}: \mathrm{C}, 64.57 ; \mathrm{H}, 4.29 ; \mathrm{N}, 12.55$. Found: $\mathrm{C}, 64.64 ; \mathrm{H}, 4.30 ; \mathrm{N}, 12.47$. 